\title{
Promoting Sustainable Food Provision; the Role of Networks in Global Food Governance
}

\author{
Peter Oosterveer* \\ Environmental Policy Group, Wageningen University, Netherlands
}

Submission: September 23, 2017 Published: October 16, 2017

${ }^{*}$ Corresponding author: Peter Oosterveer, Environmental Policy Group, Wageningen University, The Hollandseweg 1, 6706 KN Wageningen, The Netherlands, Tel: +31317485038; Email: peter.oosterveer@wur.nl

\begin{abstract}
Food provision in contemporary societies is transforming due to challenges of globalization, sustainability and equity. The interactions between civil society organizations, governments, the food industry, consumers and producers constitute dynamic fields of environmental change in global food provision. Promoting equitable and sustainable food provision in a globalizing world requires well-informed insights in these social dynamics involved because global food governance involves a complex array of different public and private actors. Today we are faced with a fragmented, differentiated, hybrid and contested constellation of global food governance arrangements and therefore we need a network rather than a formalized perspective on food governance. Such a network perspective can serve as the start of a new research agenda for the study of global sustainable food governance.
\end{abstract}

Keywords: Food; Globalization; Sustainability; Equity; Network governance

\section{opinion}

Food is farming, processing and trade, as well as nutrition and calories. But food is also a social and highly contested phenomenon in several respects, in particular on sustainability and food security. Addressing these challenges means approaching food production not in isolation but as embedded in the wider and transforming complex of activities that comprises contemporary food provision. Developing an agenda on addressing food sustainability and food security requires an in-depth understanding of these dynamics and in particular the three core dimensions that characterize them: globalization, sustainability and equity.

The first dimension is globalization: our food today is global in many respects. Most obvious is the continuous increase in international food trade [1] and although most food is still consumed in the country where it is produced, many people live in countries that are net-food importing [2]. In the future, global food trade will probably increase further and remain necessary to secure access to food in food-deficit countries and remain a source of income for farmers [3]. The global character of food provision is also evident in the complex logistics involved in processing [4] and transporting food as well as in the rapid speed that food risks may travel with [5]. Globalization should not be simply equated with uniformity and homogeneity or with a new different spatial level, but rather with the creation of more intense and speedy connections. All food is global, connected across time and space through information and trade, scientific and technological innovation and politics but also through the (moral) obligation to feed the world's population and to secure the environment for future generations. All food is also local, bounded by time and place through the specifics of climate and soils, the possibilities and limitations of the physical, social and institutional infrastructures, and the local cultures of food production and consumption. The resulting interactions between the local and the global dynamics constitute an important driver for change.

The second aspect is sustainability. Most people agree that the future of food has to be sustainable but achieving this goal proves challenging. Food depends on natural resources in production, processing and trade and these resources, including land, water, energy and fertilisers, are becoming increasingly scarce. Climate change through rising temperatures and weather volatility threatens food production as well as degrading soil quality and reducing (agro) biodiversity do. At the same time, the current food system is also responsible for environmental problems. For instance, about $25 \%$ of total greenhouse gas emissions 
originate from food [6,7]. Intensive production depends on fossil fuels and contributes to biodiversity loss and the continued and widespread use of pesticides has negative environmental and social consequences. Trade-offs between economic, social and environmental concerns are necessary although controversial and therefore sustainability of food is and will remain contested.

The third aspect is equity. Promoting access to food for all people in an equitable manner needs in-depth understanding of how global food provision operates. Access to food means we should look at people's capabilities to buy, produce or exchange food. Herein we are not just concerned with securing access to sufficient calories but also to the right mix of (micro) nutrients. Currently there are substantial inequities in access to sufficient, sustainable and healthy food as the persistent hunger and growing obesity problems around the world illustrate. Nearly 800 million people go to bed hungry and some 600 million people are considered obese [8]. These problems may become even more prominent in the future with a growing population and rising welfare. Continued economic development and rapid urbanisation will change diets [6] and intensify the challenges of securing equal access. Equity in access to food means that we should look at food in terms of distribution, health and sustainability [9].

So then, how to organize sufficient, adequate and sustainable food for all in the context of globalization, sustainability and equity, and what are the governance arrangements necessary for this? In food, national governments are no longer the only or central regulatory agent. Since the 1980s, multilateral institutions, such as the World Trade Organization (WTO), and local authorities, such as urban governments have become active in steering food provision. Non-state actors, private companies and NGOs are involved in developing standards and certification schemes. Global food governance is thus addressed by a complex array of different public and private actors leading to diverse arrangements, each with their particular goals, strategies and instruments. We are faced with a fragmented, differentiated, hybrid and contested constellation of global food governance arrangements. These varied global food governance arrangements do not have formal relationships but their interactions result in continuously in-the-making, constituted and reconstituted networks.

The (governmental and non-governmental) actors involved in steering these networks are not necessarily located in the same place and may not even be in direct contact but they interact through the network. These networks involve actors in combination with material flows of food and finances as well as with immaterial flows of information on sustainability, quality and safety of food products. Using a global network perspective allows us to analyse these contemporary food governance arrangements and to recognize the emergence of yet unknown forms of power, which operate in particular through mechanisms of in and exclusion, and through steering and connecting. Contemporary global food governance arrangements are therefore complex and constantly (re-)negotiated through networks that deal with the challenges of globalization, sustainability and equity.

Critical question for global food policy and research are therefore:

a. How are the challenges of globalization, sustainability and equity addressed in global food governance networks?

b. How are these aims and concerns institutionalized through these governance networks?

c. In what ways are the different actors in these networks connected (included or excluded) and how are the interactions between them steered?

d. What are the local impacts of global food governance networks and practices and vice-versa?

\section{References}

1. MacDonald GK, Brauman KA, Sun S, Carlson KM, Cassidy ES, et al. (2015) Rethinking Agricultural Trade Relationships in an Era of Globalization. Bio Science 65(3): 275-289.

2. Porkka M, Kummu M, Siebert S, Varis O (2013) From Food Insufficiency towards Trade Dependency: A Historical Analysis of Global Food Availability. PLoS ONE 8(12): e82714.

3. Fader M, Gerten D, Krause M, Lucht W, Cramer W (2013) Spatial decoupling of agricultural production and consumption: quantifying dependences of countries on food imports due to domestic land and water constraints. Environmental Research Letters 8(1): 014046.

4. Reardon T, Timmer CP, Minten B (2012) Supermarket revolution in Asia and emerging development strategies to include small farmers. Proceedings of the National Academy of Sciences 109(31): 1233212337.

5. Amour CB, Wenz L, Kalkuhl M, Steckel JC, Creutzig F (2016) Teleconnected food supply shocks. Environmental Research Letters 11(3): 035007.

6. Charles GHJ, Garnett T (2014) Food security and sustainable intensification. Philosophical Transactions of the Royal Society B: Biological Sciences 369(1639).

7. Wirsenius S, Hedenus F, Mohlin K (2011) Greenhouse gas taxes on animal food products: rationale, tax scheme and climate mitigation effects. Climatic Change 108(1-2): 159-184.

8. FAO, IFAD, UNICEF, WFP,WHO (2017) The State of Food Security and Nutrition in the World 2017. Building resilience for peace and food security. Rome, Italy, p. 194.

9. Wiggins S, Keats S (2015) The rising cost of a healthy diet. Changing relative prices of foods in high-income and emerging economies. Overseas Development Institute, London, p. 5. 
This work is licensed under Creative Commons Attribution 4.0 License DOI:10.19080/ARTOAJ.2017.12.555832
Your next submission with Juniper Publishers will reach you the below assets

- Quality Editorial service

- Swift Peer Review

- Reprints availability

- E-prints Service

- Manuscript Podcast for convenient understanding

- Global attainment for your research

- Manuscript accessibility in different formats

( Pdf, E-pub, Full Text, Audio)

- Unceasing customer service

Track the below URL for one-step submission https://juniperpublishers.com/online-submission.php 